\title{
Screening of the human tumor necrosis factor-alpha (TNF- $\alpha)$ gene promoter polymorphisms by PCR-DGGE analysis
}

\author{
A. Patiño-García ${ }^{1}{ }^{*}$, E. Sotillo-Piñeiro ${ }^{1}$, C. Modesto $^{2}$, L. Sierrasesúmaga ${ }^{1}$ \\ 1 Department of Paediatrics, University Clinic, University of Navarra, E-31080 \\ Pamplona, Spain \\ ${ }^{2}$ Department of Internal Medicine, Val d'Hebrón Hospital, Barcelona, Spain
}

* Corresponding author. Tel.: +34-948-425653; Fax: +34-948-425652;

E-mail: apatigar@unav.es

\begin{abstract}
We have designed a new PCR-DGGE technique that enables detection of base changes in the TNF- $\alpha$ gene promoter. Screening of 130 samples from Spanish children has shown that this technique accurately detects the altered band patterns induced by the presence of the polymorphisms at positions $-376,-308,-238$ and -163 of the promoter sequence. Although further analysis are needed to fully characterise the alterations detected, we believe that this PCR-DGGE technique is a rapid and sensitive first approach to the genetic characterisation of the TNF- $\alpha$ promoter.
\end{abstract}

\section{KEYWORDS}

PCR; DGGE; Polymorphism; TNF- $\alpha$ 


\section{INTRODUCTION}

The detection of single nucleotide variations in DNA represents a common technical obstacle in genetic analysis. These variations may represent either disease related mutations or polymorphic changes in sequences within or flanking disease genes. The development of the polymerase chain reaction (PCR) [1] has allowed the introduction of the several mutation screening methods available nowadays.

PCR-DGGE (Denaturing Gradient Gel Electrophoresis) analysis has been frequently considered the method of choice for the screening of nucleotide changes [2,3]. This technique relies on the analysis of the electrophoretic mobility of double stranded DNA molecules through linearly increasing concentrations of denaturing agents and it makes possible the detection of close to $100 \%$ base substitutions in rather long fragments (up to $600 \mathrm{bp}$ ) [4]. An additional advantage of DGGE is the possibility of simulating the melting behaviour of a DNA sequence by computer analysis using the Melt87 and SQHTX programs.

Variations within the TNF- $\alpha$ locus have been postulated to be involved in several MHC-related autoimmune diseases, both due to its role as mediator of the inflammatory response as well as its immunological activities.

Several genetic polymorphisms (positions -857, -851, -376, -308, -238 and -163) have been identified in the 5 ' transcription regulating sequences of the TNF- $\alpha$ gene $[5,6]$. Several authors have related these allelic polymorphisms, mainly those at positions -308 and -238 , with the development of certain pathologies [7-9].

The screening method of choice to test the presence of the polymorphisms described above has frequently been the single strand conformation polymorphism (SSCP) technique, followed by restriction fragment length polymorphism (RFLP) analysis or sequencing to complete the characterisation of the nucleotide variation. Given the limitations of the SSCP technique in the size of the DNA molecules which can be analysed (200 bp or less) and the difficulty in setting up the technique to achieve a high level of accuracy and sensitivity [10], we designed a PCR-DGGE reaction for the rapid screening of the region encompassing four of the polymorphisms described in the TNF$\alpha$ gene promoter. The possibility to use the DGGE method as a first screening approach, enables the minimisation of the number of samples to be digested and the avoidance of the use of radioisotopes or silver staining methods, that are expensive and usually cumbersome and time-consuming.

\section{MATERIALS AND METHODS}

DNA was extracted following standard procedures [11] from peripheral blood lymphocytes of 130 Spanish children.

\subsection{PCR reaction}

PCR primers were designed to amplify a 321 bp fragment of the TNF- $\alpha$ promoter between nucleotides -398 and -103 which can be analysed by means of DGGE when 
using a direct primer with a $25 \mathrm{nt}$ GC clamp (Fig. 1), and contains the DNA region where the TNF- $\alpha$ promoter polymorphisms -376, -308, -238 and -163 have been described. Primer sequences were: 5'GCCCGCCGTCCCGGCCCGACCCCCGTTTTC-CTGCATCCTGT CTG- $3^{\prime}$ and TNF-3R: 5'-GCTCA-TCTGGAGGAAGCGGTAG-3'.

DNA sequences were amplified in a RoboCycler ${ }^{\mathrm{TM}} 40$ (Stratagene ${ }^{\circledR}$, La Jolla, CA) thermalcycler in $50 \mu \mathrm{l}$ of reaction mix containing $250 \mathrm{ng}$ of genomic DNA, 20 pmol of each primer, $200 \mu \mathrm{M}$ dNTPs and 2 units of polymerase $\left(\right.$ BioTaq $^{\mathrm{TM}}$, Bioprobe Systems, Montreuil Sous Bois, France) in buffer containing $20 \mathrm{mM}$ Tris- $\mathrm{HCl}, \mathrm{pH} 8.55,16 \mathrm{mM}$ $\left(\mathrm{NH}_{4}\right)_{2} \mathrm{SO}_{4}, 2.5 \mathrm{mM} \mathrm{MgCl} 2$ and $150 \mu \mathrm{g} / \mathrm{ml} \mathrm{BSA}$. The amplification was performed as follows: $94^{\circ} \mathrm{C}$ for $5 \mathrm{~min}$ followed by 30 cycles of $94^{\circ} \mathrm{C}$ for $60 \mathrm{~s}, 57^{\circ} \mathrm{C}$ for $60 \mathrm{~s}$ and $72^{\circ} \mathrm{C}$ for $60 \mathrm{~s}$. Final extension was maintained at $72^{\circ} \mathrm{C}$ for $7 \mathrm{~min}$. Following PCR, heteroduplex formation was induced by incubation at $94^{\circ} \mathrm{C}$ for $10 \mathrm{~min}$ and at $56^{\circ} \mathrm{C}$ for 1 h.

\subsection{DGGE analysis}

Ten microliters of each sample were loaded on a $16 \mathrm{X} 18 \mathrm{~cm} 6.5 \%$ polyacrylamide gel (acrylamide:bisacrylamide, 37.5:1) with a denaturing gradient between 30\% (top) to $80 \%$ (bottom), being 100\% denaturant $7 \mathrm{M}$ urea and 40\% deionized formamide. The gels were maintained at $60^{\circ} \mathrm{C}$ in a Protean II electrophoresis unit (BioRad, Hercules, $\mathrm{CA})$ and electrophoresed at $160 \mathrm{~V}$ in $1 \mathrm{X}$ TAE buffer $(40 \mathrm{mM}$ Tris acetate, $20 \mathrm{mM}$ sodium acetate, $1 \mathrm{mM}$ EDTA $\mathrm{pH}$ 7.4) for $3 \mathrm{~h}$. After electrophoresis, the gels were stained with ethidium bromide and photographed under UV light (Fig. 2).

\subsection{RFLP analysis}

Samples with altered electrophoretic mobilities in DGGE gels were subjected to RFLP analysis to detect the nucleotide change/s present in each sample. We used the DNA amplification fragment described above for the detection of the polymorphisms located at -376 and -163 after digestion with the appropriate restriction enzymes: Tsp509I and BstUI, respectively.

To reveal the polymorphisms at base numbers -238 and -308 we used a modification of the protocol described by Wilson et al. [12]. Those DNA samples with altered band patterns were amplified with the following primers, direct: 5'-AGGCAATAGGTTTTGAGGGCCAT-3' and reverse: 5'-ACACTCCCCATCCTCCCGGCT-3'; the resulting product spans a $117 \mathrm{bp}$ fragment of the promoter of the TNF- $\alpha$ gene between -332 and -216 , and includes a single base change (underlined) within the 5' primer which incorporates a NcoI restriction site next to the polymorphism at position 308 and a nucleotide change in the ${ }^{\prime}$ ' primer which introduces a NlaIV site at the -238 polymorphic site. The PCR reaction was similar to the one described before except that the annealing temperature of the primers was increased to $61^{\circ} \mathrm{C}$. After amplification, the DNA fragments were digested with NcoI and/or NlaIV following the manufacturer's instructions. 
In all cases, the digestion products were loaded on to a $10 \%$ polyacrylamide gel (acrylamide:bisacrilamide, 29:1) and visualised under UV light after ethidium bromide staining.

\section{RESULTS AND DISCUSSION}

We have analyzed samples from 130 Spanish children to search for variations in the TNF- $\alpha$ genepromoter and to test a single PCR-DGGE reaction designed to detect the presence of any base change present in this region.

Primers were designed to include the nucleotide positions of interest: $-376,-308,-238$ and -163 , and a $25 \mathrm{nt} \mathrm{GC-clamp} \mathrm{was} \mathrm{attached} \mathrm{to} \mathrm{the} \mathrm{forward} \mathrm{primer} \mathrm{in} \mathrm{order} \mathrm{to} \mathrm{get} \mathrm{an}$ adequate melting map of the region, with a single melting domain containing these four positions. For further studies with these fragments designed for DGGE (as RFLP analysis), it is important to be aware that the GC-clamp must not contain any endonuclease target that may interfere with the interpretation of the results. In our reaction it was of special interest to avoid clamps carrying targets for BstUI, the endonuclease used for the detection of the polymorphism at position -163 and which has the recognition site 5'-CG/CG-3'.

It has been demonstrated in other reports [13] that the position of the altered base relative to the PCR primers plays a key role in the detection of variations, and sometimes mutations located close to the ends of the amplification fragments failed to be detected by the DGGE method. To overcome this problem, amplification with a different set of primers is often used, in order to relocate the nucleotides under analysis in the central regions of the melting domain. However, our DGGE reaction accurately detects the polymorphism at base -376 which is located only 4 bp from the 3 ' end of the forward GC-clamped primer (Fig. 1).

Eight different genotypes for the TNF- $\alpha$ promoter were found: normal/normal, normal/ -308 , normal/-376 +-238, -308/-376+-238, normal/-238, -163/-376+-238, -376/-308 and $-308 /-238$. As in previous reports, polymorphisms at -238 and -376 were found to be in linkage disequilibrium [6].

All the polymorphic samples showed band patterns clearly different from the single band present in normal individuals. Samples carrying the same genotype presented identical band pattern in DGGE gels (Fig. 2, lanes 4, 5, 7, 8 and 9) and usually, different mutant patterns corresponded to different genotypes, except certain allele combinations that were difficult to distinguish (i.e., -308/-238 and -308/normal).

To test the specificity of the technique, 30 samples that displayed normal band patterns in the DGGE gels were randomly chosen and subjected to endonuclease digestion, and all of them showed a wild type TNF- $\alpha$ promoter in the RFLP analysis. On the other hand, all the samples that showed an altered band pattern in the DGGE analysis were found to carry at least one of the polymorphisms described and, to date, we did not find any other polymorphsim or mutation in this DNA region. However, our series is being extended to further characterise the human TNF- $\alpha$ promoter in other groups of individuals. 
We conclude that the PCR-DGGE technique presented here is a useful, rapid and sensitive method to screen for polymorphisms in the human TNF- $\alpha$ promoter and can be the method of choice as a screening approach, although further analysis are needed to completely characterise the precise nucleotide changes present in the DNA.

\section{ACKNOWLEDGEMENTS}

Computer programs Melt87 and SQHTX were kindly provided by Dr. L. Lerman. We are also thankful to Dr. H. Holden from the Laboratory of Molecular Medicine of the University of Sheffield for providing us with some polymorphic samples. This work was financially supported by a PIUNA grant from the University of Navarra.

\section{REFERENCES}

1) R.K. Saiki, D.H. Gelfand, S. Stoffel, S.J. Scharf, R. Higuchi, G.T. Horn, K.B. Mullis, H.A. Erlich, Primer directed amplification of DNA with a thermostable DNA polymerase, Science 239 (1988) 487-491.

2) S.G. Fischer, L.S. Lerman, DNA fragments differing by a single base pair substitution are separated in denaturing gradient gels: Correspondence with melting theory, Proc. Natl. Acad. Sci. USA 80 (1983) 1579-1583.

3) R.M. Myers, N. Lumelski, L.S. Lerman, T. Maniatis, Detection of single base substitutions in total genomic DNA, Nature (London) 313 (1985) 495-498.

4) R. Fodde, M. Losekoot, Mutation detection by denaturing gradient gel electrophoresis (DGGE), Hum. Mutat. 3 (1994) 83-94.

5) S.M. Hermann, S. Ricard, V. Nicaud, C. Mallet, D. Arveiler, A. Evans, J.B. Ruidavets, G. Luc, L. Bara, H.J. Parra, O. Poirier, F. Cambien, Polymorphisms of the tumor necrosis factor-alpha gene, coronary heart disease and obesity, Eur. J. Clin. Invest. 28 (1998) 59-66.

6) A. Hamann, C. Mantzoros, A. Vidal-Puig, J.S. Flier, Genetic variability in the TNF- $\alpha$ promoter is not associated with type II diabetes mellitus (NIDDM), Biochem. Biophys. Res. Comm. 211 (1995) 833-839.

7) G. Bouma, B. Xia, J.B. Crusius, G. Bioque, Y. Koutroubakis, B.M. Von Blmberg, S.G. Menwissen, A.S. Pena, Distribution of four polymorphisms in the tumor necrosis factor (TNF) genes in patients with inflammatory bowel disease (IBD), Clin. Exp. Immunol. 103 (1996) 391-396.

8) S. Nadel, M.J. Newport, R. Booy, M. Levin M, Variation in the tumor necrosis factor-alpha gene promoter region may be associated with death from meningococcal disease, J. Infect. Dis. 174 (1996) 878-880.

9) F. Stuber, M. Petersen, F. Bokelmann, U. Schade, A genomic polymorphism within the tumor necrosis factor-alpha concentrations and outcome of patients with severe sepsis, Crit. Care Med. 24 (1996) 381-384.

10) V.C. Sheffield, J.S. Beck, A.E. Kwitek, D.W. Sandstrom, E.M. Stone, The sensitivity of single-strand conformation polymorphism analysis for the detection of single base substitutions, Genomics 16 (1993) 325-332.

11) J. Sambrook, E.F. Fritsch, T. Maniatis, 1989. Molecular Cloning: A laboratory manual, Cold Spring Harbor Laboratory, Cold Spring Harbor, NY. 
12) A.G. Wilson, F.S. di Giovane, A.F. Blakemore, G.W. Duff, Single base polymorphism in the human tumor necrosis factor alpha (TNF $\alpha$ ) gene detectable by NcoI restriction of PCR product, Hum. Mol. Genet. 1 (1992) 353.

13) S. Rossetti, S. Corrà, M.O. Biasi, A.E. Turco, P.F. Pignatti, Comparison of heteroduplex and single-strand conformation analyses, followed by ethidium fluorescence visualization for the detection of mutations in four human genes, Mol. Cell. Probes 9 (1995) 195-200. 
$\operatorname{Tm}\left({ }^{\circ} \mathrm{C}\right) \quad 100$

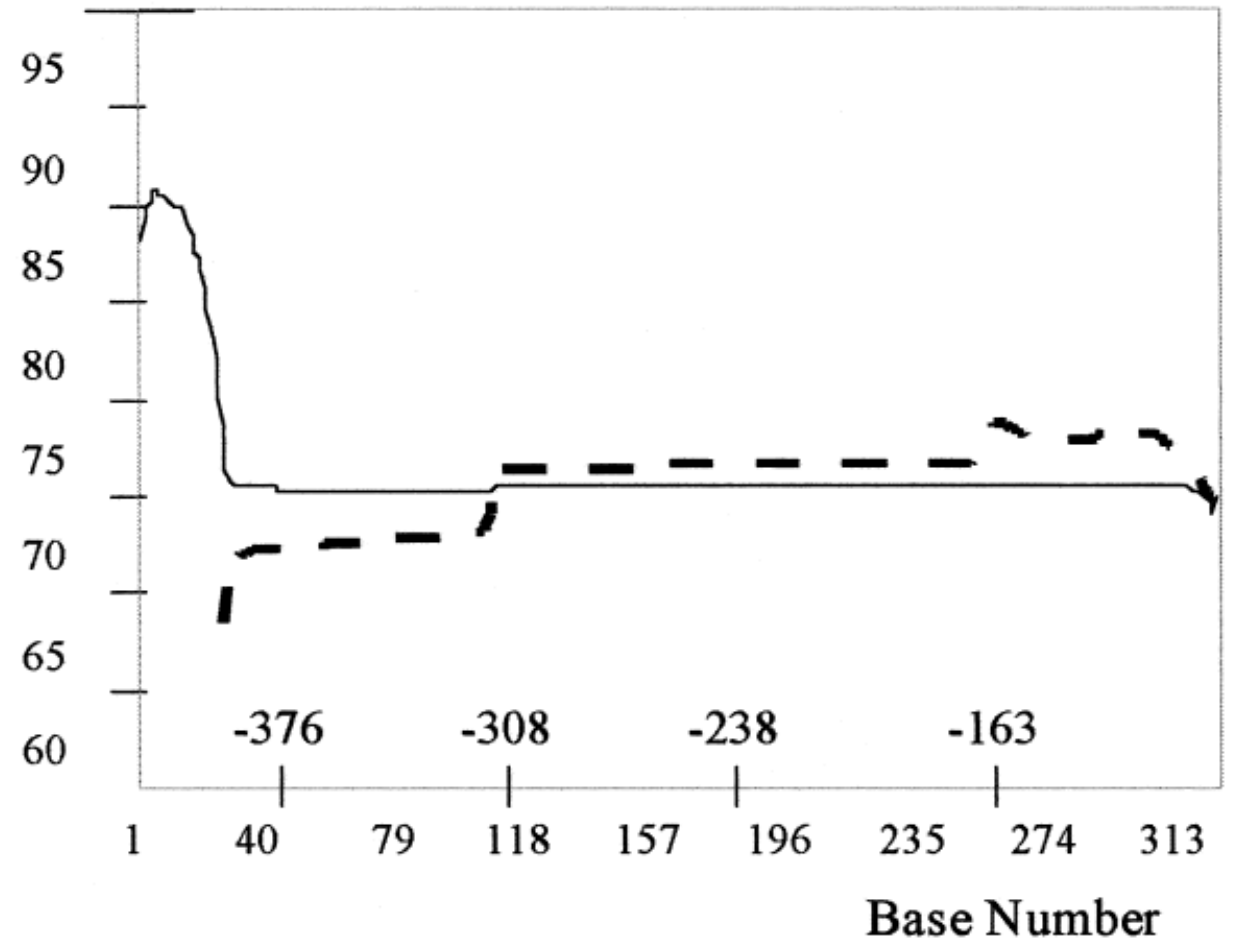

Figure 1. Melting maps of the human TNF- $\alpha$ gene promoter. Dashed line: original melting map, continuous line: melting map of the $321 \mathrm{bp} \mathrm{PCR} \mathrm{product} \mathrm{with} \mathrm{a} \mathrm{clamped}$ forward primer. The positions of the polymorphisms described are indicated.

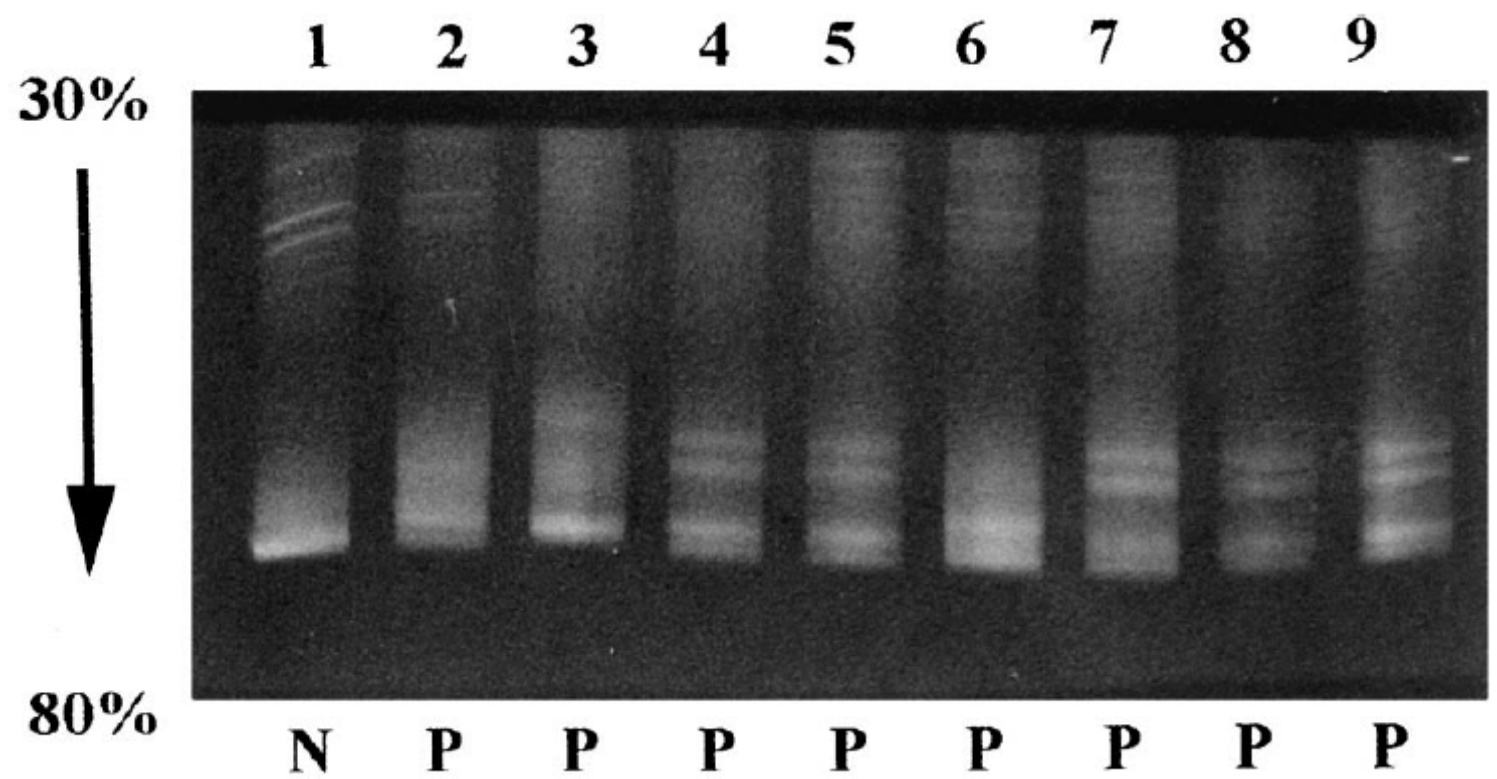

Figure 2. DGGE gel showing altered and normal patterns. Lane $1=$ normal pattern, lanes 2 to $9=$ different polymorphic patterns. 